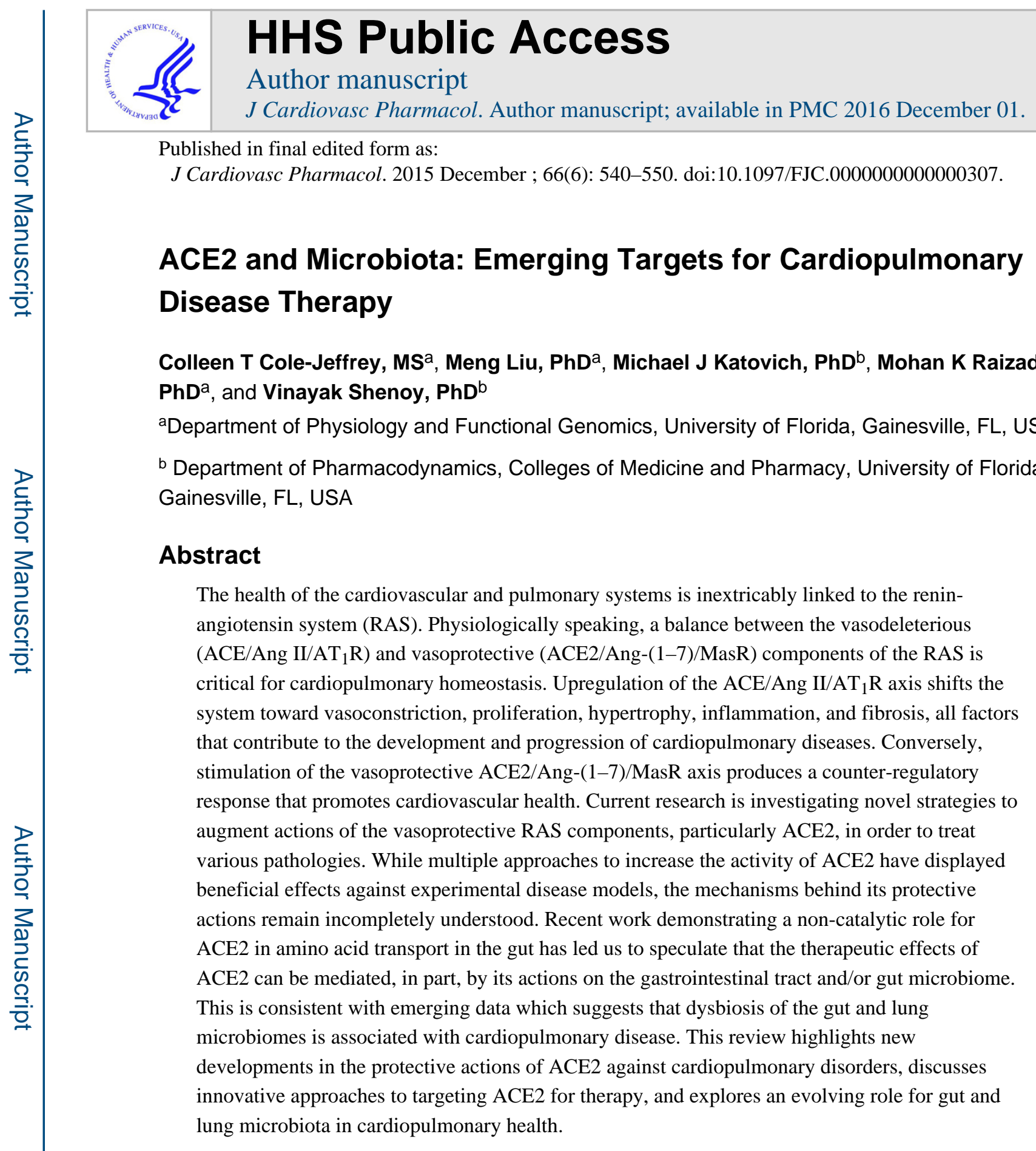

\title{
INTRODUCTION
}

The circulating renin-angiotensin system (RAS) is a hormonal system that plays a prominent role in regulating blood pressure (BP) and maintaining fluid balance in the body ${ }^{1}$, whereas local expression of the RAS in organs and tissues promotes growth, differentiation, and

Corresponding Authors:Vinayak Shenoy, Ph.D., Assistant Research Scientist, Department of Pharmacodynamics, College of Pharmacy, University of Florida, Gainesville, FL 32610, shenoyvi@ufl.edu, Phone: 352-273-7697, Fax: 352-273-7705, Mohan K. Raizada, Ph.D. Distinguished Professor, Department of Physiology \& Functional Genomics, College of Medicine, University of Florida, Gainesville, FL 32610, mraizada@ufl.edu, Phone: 352-392-9299, Fax: 352-294-0191.

Disclosures: None 
inflammation ${ }^{2,3}$. Angiotensin II (Ang II), a potent vasoconstrictor and the major effector peptide of this system, is formed as a result of enzymatic cleavage of Angiotensin I (Ang I) by Angiotensin converting enzyme (ACE) (Figure 1). Ang II exerts its actions via binding to two distinct G-protein coupled receptors: angiotensin type 1 receptor $\left(\mathrm{AT}_{1} \mathrm{R}\right)$ or angiotensin type 2 receptor $\left(\mathrm{AT}_{2} \mathrm{R}\right)$. Apart from regulating $\mathrm{BP}$, overactivity of the RAS has been implicated in the development and progression of numerous cardiovascular (CV) pathophysiologies ${ }^{4}$. In fact, ACE inhibitors (ACEi) and angiotensin receptor blockers (ARB) are the first line of treatment for patients with hypertension ${ }^{5}$ and other cardiovascular diseases $(\mathrm{CVD})^{6}$. These agents are effective for BP lowering ${ }^{7}$, as well as for attenuation of ventricular remodeling, reduced incidence of myocardial infarction (MI), and prevention of the development of heart failure $(\mathrm{HF})^{8}$.

The recent discovery of several new RAS components has altered the way RAS is perceived in the field. Of particular significance was the identification of Angiotensin converting enzyme 2 (ACE2) ${ }^{9,10}$, a monocarboxypeptidase, which cleaves Ang II into Angiotensin-(17) [Ang-(1-7)]. Ang-(1-7) is a vasodilatory heptapeptide that acts through the Mas receptor (MasR) to mediate anti-proliferative, anti-fibrotic, and anti-inflammatory effects ${ }^{11-13}$. These observations have led to the proposal that the angiotensin system is composed of two opposing arms, with ACE, Ang II, and $\mathrm{AT}_{1} \mathrm{R}$ representing the deleterious axis [ACE-Ang II$\mathrm{AT}_{1} \mathrm{R}$ ], whereas ACE2, Ang-(1-7), and MasR represent the beneficial axis [ACE2-Ang-(17)-MasR] (Figure 1). Under physiological conditions, there exists a balance between these two axes, which aids in maintenance of cardiopulmonary homeostasis. Upregulation of the vasodeleterious axis leads to vasoconstriction, hypertrophy, inflammation, and cardiac remodeling ${ }^{14}$. In contrast, stimulation of the vasoprotective RAS axis either by genetic overexpression ${ }^{13,15,16}$, peptide infusion ${ }^{17}$, or administration of synthetic molecules ${ }^{18}$ yields valuable cardiopulmonary effects. Despite these beneficial actions of the vasoprotective axis in restoring cardiopulmonary function, the mechanism(s) by which ACE2 mediates its protection are not completely understood. In this review, we present evidence of the direct and indirect actions of ACE2 on the cardiopulmonary system. ACE2-mediated effects on cardiac and pulmonary tissues include vasodilation, anti-hypertrophy, anti-proliferation, and anti-fibrosis (Figure 2). Furthermore, ACE2 treatment has been shown to improve endothelial function ${ }^{19}$, facilitate angiogenesis ${ }^{20,21}$, and enhance progenitor cell function ${ }^{22}$, all of which promote cardiopulmonary health. Additionally, ACE2 exerts favorable actions on the bone marrow (BM), brain, and gastrointestinal system, which provide indirect benefit to the cardiopulmonary system. With regards to its actions on the BM, ACE2 improves the migratory potential of stem/progenitor cells to aid regeneration of the injured cardiopulmonary tissue. ACE2 also increases nitric oxide (NO) production in BM-derived progenitor cells ${ }^{23}$ and enhances vascular repair ${ }^{22,23}$. Similarly, ACE2 acts on the brain to improve baroreflex sensitivity ${ }^{24}$, reduce sympathetic outflow ${ }^{25}$, and decrease $\mathrm{BP}^{26}$. It is generally believed that the benefits of ACE2 on the heart, lungs, brain, and progenitor cells are primarily mediated by a reduction in Ang II and subsequent elevation in Ang-(1-7) levels. However, other factors may be involved as well. Recent work has highlighted noncatalytic roles for ACE2 in amino acid transport and expression of antimicrobial peptides in the gut. Along with this, the role of gut and lung microbiota in promoting cardiorespiratory health is rapidly emerging. Thus, we propose that ACE2 might also exhibit cardiopulmonary 
protection via alterations in the gut and/or lung microbiomes, which may open new avenues for therapeutic interventions. In this review, we will discuss our current understanding of the role of ACE2 in cardiopulmonary diseases, discuss various strategies to target this enzyme for translational applications, and explore the concept that the beneficial effects of ACE2 on cardiopulmonary disorders may be mediated by changes in microbiota. For this purpose, an extensive search was performed for literature from the last 20 years, utilizing PubMed and other scholarly search bibliographic databases with a variety of terms that included ACE2, renin angiotensin system, pulmonary hypertension, $\mathrm{CV}$ disease, and microbiota.

\section{THE CARDIOVASCULAR SYSTEM}

\section{ACE2 Polymorphisms in Hypertension and Ventricular Hypertrophy}

A multitude of research has focused on the role of ACE2 in the CV system. Given that ACE2 maps to a defined quantitative trait locus on the $\mathrm{X}$ chromosome in different animal models of hypertension, several studies were carried out to investigate whether common single-nucleotide polymorphisms in the human ACE2 locus correlate with changes in BP and cardiac function. It was observed that the ACE2 variant G8790A was significantly associated with essential hypertension in females and in Han-Chinese males ${ }^{27}$. Furthermore, Patel et al. ${ }^{28}$ reported that genetic variation in ACE2 in Caucasians with type 2 diabetes was associated with hypertension and reduced systolic function in men, whereas ACE2 variation in women was associated with hypertension and increased left ventricular (LV) mass. This gender-specific data is especially interesting in light of new evidence that a partial loss of Xlinked ACE2 enhances susceptibility to heart disease (HD) in response to CV stressors ${ }^{28}$. Furthermore, in line with the above findings, several other groups have shown that polymorphisms in the ACE2 gene are linked to cardiac hypertrophy ${ }^{29,30}$. However, discrepancies exist between various studies regarding the association of ACE2 polymorphisms with hypertension and cardiac function. These inconsistencies may arise from differences in the gender, ethnicity, or etiology of subject populations under consideration $^{31}$. Nonetheless, all of these observations emphasize the importance of the ACE2 gene in regulating CV function.

\section{ACE2 in Cardiovascular Disease: Lessons from Animal Models}

CVD is the leading cause of death for both men and women in the United States ${ }^{32}$. While the etiology of this disease is complex, it is well-established that the development and progression of CVD is accelerated by the actions of Ang II. One mechanism by which ACE2 is thought to prevent end-organ damage is via degradation of Ang II. In this regard, reduced ACE2 gene expression should favor increased levels of Ang II and promote tissue injury, a contention supported by several animal studies. For instance, increased concentration of cardiac Ang II ${ }^{33,34}$ and reduced levels of myocardial Ang-(1-7) ${ }^{34}$ were observed in ACE2 knockout (ACE2-KO) mice. These gene-ablated mice displayed enhanced susceptibility to cardiac problems when subjected to chronic Ang II infusion or pressure overload $^{33-35}$. Furthermore, these studies revealed that ACE2-KO mice exhibited maladaptive cardiac remodeling in terms of increased ventricular hypertrophy ${ }^{33-35}$, excessive fibrosis ${ }^{34,35}$, heightened superoxide production $^{34,35}$, and decreased cardiac contractility ${ }^{33}$. In a separate study, Trask et al. ${ }^{36}$ demonstrated that chronic ACE2 inhibition 
resulted in excessive accumulation of cardiac Ang II and worsening of ventricular remodeling in (mRen2)27 transgenic rats. Subsequently, a report by Sahara et al. ${ }^{37}$ revealed that ACE2 deletion promoted the development of atherosclerosis and arterial neointima formation, highlighting the importance of ACE2 in conferring vascular protection. Conversely, overexpression of ACE2 in the myocardium or treatment with recombinant human ACE2 protein (rhACE2) prevented cardiac remodeling following chronic Ang II infusion ${ }^{35,38}$, pressure overload ${ }^{39}$, or $\mathrm{MI}^{40}$. Preliminary studies in our lab have demonstrated that global ACE2 overexpression in mice reduces cardiac injury and remodeling following MI (unpublished data). These findings are consistent with previous reports illustrating that adenoviral-mediated overexpression of ACE2 resulted in decreased ACE and Ang II in the myocardium ${ }^{40,41}$. Likewise, treatment with rhACE2 caused enhanced plasma Ang-(1-7) levels along with reduced plasma and myocardial Ang $\mathrm{II}^{35}$. These data suggest that ACE2 expression is essential for $\mathrm{CV}$ protection.

\section{ACE2: A Biomarker for Heart Failure}

ACE2 is expressed in various cellular compartments of the heart including the cardiac endothelial cells and vascular smooth muscle cells, as well as in cardiomyocytes ${ }^{42}$. It has been observed that the expression of ACE2 is highly regulated by pathological stimuli and tissue insult. In this regard, animal studies have revealed increased levels of ACE2 mRNA and protein following myocardial injury ${ }^{42,43}$. Consistent with these findings, Zisman et al. ${ }^{44}$ demonstrated that ACE2 protein and activity were significantly elevated in failing human hearts, resulting in increased Ang-(1-7) and decreased Ang II levels. ACE2 was also found to be upregulated in idiopathic dilated and ischemic cardiomyopathies ${ }^{31}$. However, due to the complexity of CVD etiology, ACE2 expression in failing human hearts remains controversial $^{42,45-48}$. Nonetheless, these observations suggest that an elevation in cardiac ACE2 levels could serve as a compensatory mechanism to impede progression of $\mathrm{HF}$.

Traditionally, ACE2 has been thought of as a tissue-bound enzyme; however, recent reports have detected and measured soluble ACE2 (sACE2) in circulating human plasma. In fact, sACE2 activity was found to be increased in patients with $\mathrm{HD}^{49-53}$, which positively correlated with disease severity ${ }^{49-51,53}$, end systolic diameter ${ }^{53}$, end diastolic diameter ${ }^{53}$, and infarct size ${ }^{52}$, whereas it correlated negatively with ejection fraction ${ }^{52,53}$. Interestingly, sACE2 activity was also elevated in hypertensive patients with impending $\mathrm{HF}^{53}$. Thus, sACE2 could be a potential biomarker of cardiac dysfunction in patients with hypertension and HF. However, recent work by Shao et al. ${ }^{54}$ appears to run counter to the idea that increased ACE2 activity is suggestive of worsening disease. This study found that a $50 \%$ increase in baseline sACE2 levels following intensive medical therapy in acutely decompensated HF patients was predictive of improved clinical outcomes. We speculate that these discrepancies may be due to differences in etiology, patient populations, disease stages, or medical therapies. While these disparities warrant further investigation, the current evidence is highly indicative of a cardioprotective role for ACE2 in humans and suggests that differential regulation of ACE2 may have important functional consequences in CVD. 


\section{Brain ACE2 Effects on Cardiovascular Disease}

The role of the brain in development and perpetuation of CVD, namely hypertension and HF, is well established. ACE2 is widely expressed in the brain, particularly in areas involved in regulation of $\mathrm{CV}$ function. Whereas sACE2 activity in the plasma appears to be increased in pathological states, ACE2 expression was found to be considerably reduced in the brains of animals with hypertension ${ }^{24,26,55}$, neurogenic hypertension ${ }^{56}$, and chronic $\mathrm{HF}^{25,57}$. This is consistent with studies showing that ACE2 gene deletion from brain regions led to impaired baroreflex and autonomic functions ${ }^{58}$. On the other hand, genetic overexpression of ACE2 in the brain decreased $\mathrm{BP}^{26}$, reduced sympathetic outflow ${ }^{25}$, increased baroreflex sensitivity ${ }^{24}$ and attenuated neurogenic hypertension ${ }^{59,60}$. In addition, brain ACE2 overexpression increased expression of endothelial and neuronal nitric oxide (NO) synthase $^{56}$, augmented NO release ${ }^{56}$, reduced pro-inflammatory cytokines ${ }^{60}$, and decreased reactive oxygen species ${ }^{61}$, all factors that contribute to lowering of BP. These data support a role for ACE2 in regulation of $\mathrm{CV}$ functions via actions on the brain.

\section{ACE2 in Circulating Cells}

It is becoming evident that interplay between organs and BM-derived circulating cells is critical for disease prevention. A number of cardiopulmonary disorders have documented imbalances in the circulating levels of reparative and inflammatory cells (ICs), which contribute to inflammation and impaired vascular repair. We have begun to investigate the central mechanisms involved in the regulation of BM-derived cells. Retrograde neuronal tracing via injection of pseudorabies virus into the BM established a functional connection between the brain and $\mathrm{BM}^{62}$. Further studies from our group have demonstrated that the interaction between the autonomic nervous system and BM is dysfunctional in hypertensive rats, a finding associated with increased ICs and decreased endothelial progenitor cells $(\text { EPCs })^{63}$. Progenitor cells, specifically EPCs, are vital for vascular endothelial repair ${ }^{64}$, and reduced numbers and function of EPCs have been observed in patients with cardiopulmonary disease ${ }^{65-68}$. The vasoprotective RAS has demonstrated a role in improving the number ${ }^{69}$ and function ${ }^{22,23}$ of progenitor cells. In fact, animals treated with the ACE2 activator, diminazene aceturate (DIZE), displayed increased circulating EPC levels, improved engraftment of cardiac progenitor cells into the heart, and decreased ICs in the infarcted heart ${ }^{70}$. DIZE also normalized the decrease in EPC proliferation and migration associated with monocrotaline (MCT)-induced pulmonary arterial hypertension $(\mathrm{PAH})^{71}$. Consistent with this, the EPCs of patients with PAH demonstrated a reduction in migratory potential in vitro, which was improved with DIZE treatment ${ }^{71}$. Similarly, genetic modification of BM- ${ }^{72}$ or umbilical cord blood ${ }^{73}$ derived mesenchymal stem cells (MSCs) with ACE2 yielded cardiopulmonary protective effects. Work from our own group has demonstrated that NO production was significantly increased in BM-derived MSCs overexpressing ACE2 and Ang-(1-7) (Figure 2). Thus, ACE2 is vital for the function and balance of circulating progenitor cells and ICs. 


\section{THE PULMONARY SYSTEM}

\section{Role of ACE2 in Lung Injury}

The benefits of the RAS vasoprotective axis are not only limited to the CV system; studies over the past few years have highlighted the salutary effects of ACE2 on lung pathophysiology. With regards to pulmonary disease, ACE2 came into prominence when it was identified as a functional receptor for the SARS coronavirus (SARS-CoV), the etiological agent of severe acquired respiratory syndrome (SARS) ${ }^{74}$. It has been observed that SARS infection reduces pulmonary ACE2 expression and also leads to lung failure and death. This connection between ACE2 expression and lung pathophysiology is further supported by studies conducted on ACE2-KO mice, which demonstrated increased susceptibility to acute lung injury ${ }^{75}$. Recently, ACE2 was also implicated in protection against influenza-induced lung injury. For instance, ACE2 deficiency worsened disease pathogenesis in $\mathrm{H} 7 \mathrm{~N} 9$ virus-induced lung injury ${ }^{76}$. In addition, ACE2-KO mice displayed increased severity of H5N1-induced lung injury ${ }^{77}$. Consistent with this evidence, H5N1 ${ }^{77}$ and $\mathrm{H} 1 \mathrm{~N} 1{ }^{78}$ infection decreased lung ACE2 expression in wild-type mice. Furthermore, patients with H5N1 exhibited increased levels of serum Ang II, a finding recapitulated in murine models of $\mathrm{H} 5 \mathrm{~N} 1$ infection $^{77}$. Interestingly, treatment with rhACE2 restored lung function in ACE2 null mice following H5N1-induced lung pathogenesis ${ }^{77}$. Taken together, these data suggest that pulmonary ACE2 is protective and that treatments targeting this enzyme might be effective in attenuating acute lung injury.

\section{ACE2 in Pulmonary Arterial Hypertension}

PAH is a fatal lung disease characterized by increased BP in the pulmonary circulation. A growing body of work has focused on the importance of ACE2 in PAH and associated right HF. Decreased lung ACE2 expression ${ }^{79,80}$ and enzymatic activity ${ }^{81}$, along with increased circulating Ang II levels ${ }^{82}$, have been observed in PAH. Additionally, reduction in circulating ACE2 and Ang-(1-7) levels has been observed in patients with PAH from congenital $\mathrm{HD}^{83,84}$. Moreover, auto-antibodies to ACE2 predisposed patients with connective tissue diseases to development of $\mathrm{PAH}^{85}$. These clinical findings suggest that enhancement of ACE2 could provide pulmonary protection. In this regard, animal studies have shown that overexpression of ACE2 ${ }^{86}$ or administration of rhACE2 ${ }^{87}$ attenuated PAH and were associated with improved structural and functional changes in the right heart in several models ${ }^{16,39,86}$. Thus, elevating levels of circulating ACE2 could be a viable option to improve cardiopulmonary function in the clinical setting of PAH.

\section{ACE2 in Pulmonary Fibrosis}

Pulmonary fibrosis (PF) is a devastating disease marked by scarring of the lung tissue, and recent research emphasizes the contributions of ACE2 in protection against PF. Studies by $\mathrm{Li}$ et al. ${ }^{88}$ were the first to show that lung ACE2 expression and activity were severely downregulated in humans and in animal models of lung fibrosis. Along the same lines, ACE2-KO mice were more prone to bleomycin-induced lung injury ${ }^{89}$. Conversely, pulmonary overexpression of ACE2 by gene delivery or administration of rhACE2 attenuated $\mathrm{PF}^{16,89}$. Collectively, these observations suggest a potent anti-fibrotic role for ACE2 in animal models of PF. 


\section{THE GASTROINTESTINAL SYSTEM}

The above data clearly indicate that ACE2 is beneficial to the cardiopulmonary system.

These favorable effects could be manifested in a paracrine-like manner via alteration of the local RAS. However, the indirect effects of ACE2 on modulation of circulating molecules, including Ang-(1-7), cannot be ruled out. Nevertheless, it appears that the therapeutic potential of ACE2 may be more pronounced than that of Ang-(1-7). Thus, we propose that ACE2 has a multifunctional role in providing cardiopulmonary protection. This view is supported by recent evidence: i) Oral feeding of ACE2 attenuates PAH with only a modest increase in plasma Ang-(1-7) ${ }^{81}$, and ii) ACE2 plays a non-catalytic role in gut biology and modulation of gut microbiota composition ${ }^{90}$. This has led us to speculate if the beneficial effects of ACE2 on the cardiopulmonary system are partially mediated by changes in the gut microbiome.

\section{Role of ACE2 in the Gut}

Research in the last few years has highlighted an important non-RAS-related role for ACE2 in amino acid transport and gut microbiota composition. Work by Harmer et al. ${ }^{91}$ demonstrating high levels of ACE2 expression within the human gastrointestinal tract suggested a functional role for ACE2 in this system. However, the discovery of Collectrin, a regulator of neutral amino acid transporters in the kidney, provided the first evidence of a non-catalytic role for ACE2 ${ }^{92}$. Similar to ACE2, Collectrin is a type 1 transmembrane protein that shares $47.8 \%$ identity with the extracellular, transmembrane, and cytosolic domains of ACE $2^{92}$. The physiological role of Collectrin in amino acid reabsorption/ transport in the kidneys via its association with the Slc6 family of neutral amino acid transporters ${ }^{93}$ raised the question of a similar function for ACE2. One of these neutral amino acid transporters, $\mathrm{B}^{0} \mathrm{AT} 1$, colocalizes and interacts with ACE2 on small intestine brush border membranes ${ }^{94}$, where Collectrin is absent. In fact, ACE2 binds and stabilizes $\mathrm{B}^{0} \mathrm{AT} 1$ in the small intestine, and the transport activity of $\mathrm{B}^{0} \mathrm{AT} 1$ is dramatically stimulated by coexpression with $\mathrm{ACE} 2{ }^{95}$. Important work by Hashimoto et al. ${ }^{90}$ linked the amino acid transport function of ACE2 to the microbial ecology in the gut. Their studies were the first to demonstrate that ACE2- KO animals had reduced levels of neutral amino acids in the serum and, specifically, displayed impairment in uptake of tryptophan (Trp). ACE2 mutants also exhibited decreased expression of antimicrobial peptides and showed altered gut microbial composition, which was restored by tryptophan administration ${ }^{90}$. Interestingly, a recent study by Murr et al ${ }^{96}$ found that coronary artery disease (CAD) patients with low serum tryptophan concentrations displayed reduced life expectancy. These findings support the idea that ACE2 effects on gut microbiota could positively influence the CV system.

On the other hand, ACE2 cardioprotective actions could be mediated directly via antimicrobial peptides, independent of changes in gut microbiota. Antimicrobial peptides themselves have demonstrated effects on the cardiopulmonary system through functions other than antimicrobial activity. The myocardial expression of LL-37 and $\beta-2$ defensin increased following hypoxia, and LL-37 treatment enhanced the migration of human circulating peripheral blood stem and progenitor cells (PBSPCs) ${ }^{97}$, raising the possibility that some antimicrobial peptides may aid in the homing of PBSPCs to injured myocardium. 
Another antimicrobial peptide, PR-39, has also demonstrated cardioprotection via prevention of leukocyte adhesion and emigration ${ }^{98}$, as well as suppression of superoxide release ${ }^{99}$. Interestingly, the role of antimicrobial peptides may not be so straightforward. The alpha defensins, for one, have been linked to atherosclerosis ${ }^{100-102}, \mathrm{CAD}^{103}$, and STsegment elevation $\mathrm{MI}^{103}$. In addition, the antimicrobial peptide LL-37 is highly expressed in atherosclerotic plaques and has been implicated in modulation of the vessel inflammatory response ${ }^{104}$. Taken together, these data implicate antimicrobial peptides in both cardiopulmonary health and pathophysiology, and their actions may be one mechanism by which ACE2 mediates its protective effects.

\section{Gut Microbiota and Cardiovascular Disease}

The gut microbiome is emerging as a critical player in health and disease. Reports have drawn associations between intestinal dysbiosis and metabolic diseases, including obesity and type 2 diabetes ${ }^{105}$, both of which are considered major risk factors for developing $\mathrm{CVD}^{106}$. A recent study by our group has also demonstrated a link between gut dysbiosis and hypertension ${ }^{107}$. These findings are consistent with clinical studies which suggest that consumption of probiotics improves $\mathrm{CV}$ health. Namely, probiotics have been reported to reduce $\mathrm{BP}^{108-115}$, decrease oxidative stress ${ }^{116-123}$, positively alter cholesterol concentrations ${ }^{108,109,124-126}$, and release ACE-inhibiting peptides ${ }^{127}$. More recently, alterations in the gut microbiota have been directly implicated in the pathogenesis of CVD. For instance, infants with congenital heart defects showed reduced total bacterial count as compared to healthy infants ${ }^{128}$, and atherosclerotic plaques were found to house microbiobes ${ }^{129}$. Furthermore, administration of probiotics has been successful in decreasing $\mathrm{BP}$ and delaying the development of $\mathrm{HF}$ in rats following $\mathrm{MI}^{130}$. Interestingly, BP reduction may be mediated by the effects of probiotics on autonomic neurotransmission. In support of this hypothesis, intraduodenal injection of Lactobacillus johnsonii resulted in reduced renal sympathetic nerve activity and increased gastric vagal nerve activity ${ }^{131}$. Consistent with these findings, others have reported that communication between the nervous system and microbiota may occur via afferent sensory neurons in the gut ${ }^{132}$. In fact, there is evidence that stress-induced intestinal permeability allows enhanced uptake of bacterial antigens ${ }^{133}$, allowing for modulation of the central nervous system through immune and enteric nervous system pathways. It is believed that probiotics may attenuate this stress-induced hyperpermeability ${ }^{134}$. Collectively, these data raise the question of whether the beneficial effects of enhanced ACE2 expression and activity on HF and hypertension are partly a result of altered gut microbiota and subsequent modified autonomic inputs to the CNS.

\section{LUNG MICROBIOME AND PULMONARY DISEASE}

The respiratory tract houses its own microbiome, and Dickson et al. ${ }^{135}$ have proposed a model in which inflammation in response to a trigger alters lung conditions and affects the ability of various microbes to immigrate or be eliminated, thus favoring the growth of some microbes over others. This is supported by studies that have demonstrated lung dysbiosis during exacerbations of respiratory diseases ${ }^{135}$. Specifically, progression of idiopathic PF is associated with increased presence of Staphylococcus and Streptococcus bacteria ${ }^{136}$. Interestingly, pulmonary dysfunction is often related to bowel disease ${ }^{137}$; however, the 
connection between the lung and the gut is not completely understood. Recent work investigating microbiomes in infants with cystic fibrosis discovered an overlap in bacterial genera present in the gut and respiratory tract, with some populations that change similarly over time ${ }^{138}$. Additionally, numerous studies have demonstrated that entericallyadministered probiotics prevent upper respiratory tract infections ${ }^{139}$. Though these studies have not addressed the mechanisms behind the observed pulmonary benefits, we speculate that probiotics could modulate the gut microbiome to favorably alter the nervous system and circulating cells to exert respiratory protection. In addition, benefits may result from a direct connection between gut and lung microbiomes. It will be interesting to investigate whether the benefits of ACE2 on pulmonary diseases may be mediated via modulation of gut and/or lung microbiota populations.

\section{CLINICAL PERSPECTIVES OF ACE2-TARGETED THERAPIES}

\section{Recombinant Human ACE2 Protein}

Treatment with rhACE2 has demonstrated protection against a variety of experimental disease models that are associated with elevated levels of Ang II or a dysregulated RAS ${ }^{140}$. Encouraging results from animal studies have resulted in the initiation of clinical trials using rhACE2. Single or multiple injections of rhACE2 have been well-tolerated by healthy subjects, with no serious adverse effects or dose-limiting toxicity ${ }^{141}$. Currently, GlaxoSmithKline is testing the therapeutic potential of GSK2586881 (formerly APN01), a soluble form of rhACE2, against acute lung injury. In another trial, rhACE2 is under evaluation for the treatment of PAH (ClinicalTrials.gov; NCT01884051). Although rhACE2 is in clinical trials, there appear to be several limitations that undermine the success of protein therapeutics. One of the major hurdles is the high cost associated with recombinant protein manufacturing. Furthermore, protein stability, repetitive intravenous administration, and patient compliance pose challenges in realizing the true benefits of rhACE2 therapy.

\section{ACE2 Activators}

An effective approach to overcome the limitations of protein therapy would be to identify synthetic compounds that can enhance the activity of endogenous ACE2 protein. In 2008, our group was the first to discover several synthetic activators of ACE2 while employing a structure-based drug design ${ }^{18}$. These small molecule ACE2 activators included resorcinolnaphthalein ${ }^{18}, 1$-[[2-(dimethyl amino) ethyl] amino]-4-(hydroxymethyl) - 7-[[(4methylphenyl) sulfonyl] oxy]-9H-xanthone $9(\mathrm{XNT})^{18}$, and DIZE ${ }^{142}$. Among these three compounds, it was observed that DIZE is the most potent, followed by XNT, and finally resorcinolnaphthalein. DIZE, an antiprotozoan chemotherapeutic agent, was shown to exert beneficial effects against heart and lung diseases. For example, DIZE provided cardioprotective effects in a rodent model of $\mathrm{MI}^{70}$ and was effective in preventing the development of PAH in the MCT, bleomycin, and hypoxia models ${ }^{71}$. Similarly, chronic treatment of spontaneously hypertensive rats (SHR) with XNT prevented an increase in systemic BP, along with improving cardiac contractility ${ }^{18}$. Furthermore, in the MCTinduced rat model of PAH, administration of XNT resulted in lowering of right ventricular systolic pressure (RVSP) ${ }^{143}$, a surrogate marker of pulmonary pressure. This data is supported by studies using another ACE2 activator, resorcinolnaphthalein, which provided 
protection against MCT-induced PAH by improving endothelial function, modulating cytokine release, and reducing right ventricular hypertrophy ${ }^{79,144}$. However, certain issues hamper the successful translation of these ACE2 activators into the clinic. XNT has an undesirable pharmacokinetic profile with poor water solubility and requires acidic $\mathrm{pH}$ for solubilization, thus making it an undesirable drug entity ${ }^{18}$. On the other hand, DIZE is associated with severe toxic effects. Chronic DIZE administration can result in renal, hepatic and brain injury, which could be life-threatening ${ }^{145}$. Besides, DIZE is mutagenic, but not teratogenic ${ }^{145}$. Nonetheless, XNT and DIZE could serve as lead molecules that could be structurally modified for clinical use.

A recent report from the Batlle group challenged the idea that the benefits of XNT and DIZE are mediated via activation of $\mathrm{ACE} 2^{146}$. Using in vivo mouse experiments, they have shown that the BP-lowering effects of XNT were not blocked by the ACE2 inhibitor, MLN-4760, and that XNT decreased BP even in ACE2-KO animals. Furthermore, XNT-treated animals demonstrated no difference in kidney or serum ACE2 activity, plasma Ang II levels, or plasma Ang-(1-7) levels as compared with controls. Additionally, neither XNT nor DIZE was capable of increasing ACE2 activity in vitro or ex vivo ${ }^{146,147}$. This is in stark contrast to data published by our group and others which have demonstrated the ability of these activators to enhance ACE2 enzymatic activity in vitro and in vivo. A number of publications have recorded in vitro increases in the enzymatic activity of rhACE2 following incubation with XNT ${ }^{18,142,148}$, DIZE ${ }^{71,142}$, or resorcinolnaphthalein ${ }^{18}$. Similar results have been obtained from in vivo studies as well, as XNT was shown to increase ACE2 activity in thrombi ${ }^{149}$ and cardiac tissue ${ }^{150}$ of hypertensive rats. Additionally, administration of DIZE increased ACE2 activity in the retina ${ }^{151}$, kidney ${ }^{152}$, lungs l1 $^{71}$, heart ${ }^{70}$ and plasma ${ }^{70}$. Both XNT and DIZE were found to significantly increase plasma Ang-(1-7) levels ${ }^{148,152}$, which is a further indication of the direct effects of these small molecules on ACE2. A recent study demonstrated that restoration of impaired endothelial-dependent relaxation (EDR) in $d b / d b$ mice by DIZE treatment was ACE2-mediated. This group showed that Ang-(1-7), but not DIZE, rescued EDR in aortas from ACE2-KO animals ${ }^{153}$. Moreover, the protective effects of XNT on endothelial function ${ }^{148}$ and MCT-induced $\mathrm{PAH}^{143}$ were attenuated by coadministration of the MasR antagonist A-779. Likewise, the benefits of resorcinolnaphthalein on $\mathrm{PAH}^{79}$ and of DIZE on cerebral ischemia ${ }^{154}$ were abolished by blockage of the MasR. Co-administration of the ACE2 inhibitor, C-16, also blocked the positive effects of DIZE on $\mathrm{PAH}^{71}$. Furthermore, DIZE failed to elicit beneficial effects on cholesterol metabolism and abdominal aortic aneurysms in ACE2-KO mice ${ }^{152}$. The recent discovery of a novel ACE2 activator, NCP-2454, provides additional support for the idea that ACE2 activators do indeed enhance activation of ACE2 both in vitro and in vivo ${ }^{155}$. This mountain of data provides evidence that these compounds are, indeed, ACE2 activators. However, this does not rule out potential off-target effects of XNT and DIZE in addition to ACE2 activation. The observed discrepancies may be attributed to differences in dosages, duration of drug administration, and animal strains used in the different experimental protocols. 


\section{Genetic Modification of Stem and Progenitor Cells}

Pharmacotherapies including beta blockers, ACEi, ARBs, and anti-mineralocorticoids are used to attenuate maladaptive cardiac remodeling associated with various $\mathrm{HD}^{156}$. In addition, interventional or surgical methods are employed to improve heart function. Despite these therapies, the prognosis for patients diagnosed with HF remains poor ${ }^{157}$. As a result, researchers are exploring cell-based therapies as a means of regenerating the damaged myocardium. In this context, administration of EPCs, BM- or adipose-derived MSCs, and umbilical cord blood cells are being evaluated for their potential to offer cardioprotection. However, many hurdles still exist before the benefits of cell therapy in humans may be fully realized. For example, the hostile environment of the injured tissue, characterized by inflammation and high oxidative stress, could impair engraftment of the injected progenitor/ stem cells. We believe that overexpression of ACE2 in these cells could improve their survival and enhance their potential to effectively repair tissue injury. In fact, we have shown that ACE2 priming of EPCs not only enhances their function ${ }^{22,23}$ but also increases their therapeutic efficacy to render protection against stroke ${ }^{23}$. Recently, umbilical cord- or BM-derived MSCs were more effective in rescuing lung injury compared to MSCs alone ${ }^{72,158}$. Autologous stem cell transfer is attractive for clinical therapy because it eliminates the possibility of an adverse immune response by the host and also overcomes the toxicity of immunosuppressive medications. We believe that improving the function of progenitor/stem cells through genetic modification may hold promise for treating cardiopulmonary disorders.

\section{Bioencapsulation of ACE2}

The most preferred means of drug administration is via the mouth. However, therapeutic proteins such as ACE2 cannot be given orally due to degradation by the acidic environment of the gastrointestinal tract. To overcome this issue, we have developed an oral delivery platform that utilizes transplastomic technology to bioencapsulate ACE2 within plant leaves ${ }^{81}$. Production of therapeutic proteins using transplastomic technology has multiple benefits over conventional transgenic plants and mammalian systems, including high expression of transgenes, the ability to produce in bulk, low maintenance and cost requirements, use of the operon for expression of multiple genes simultaneously, minimized risk of contamination from human pathogens, and improved biological containment due to the maternal inheritance of plastids ${ }^{81,159,160}$. A major advantage of this technology is that chloroplast expression of ACE2 enables bioencapsulation within plant cells, such that it is protected from gastric enzymatic degradation upon oral delivery. We observed that oral feeding of rats with bioencapsulated ACE2 attenuated MCT-induced PAH and was associated with improved right heart function ${ }^{81}$. This oral delivery platform holds great potential for the clinical development of ACE2 therapy.

\section{CONCLUSION}

The evidence presented here reinforces the idea that enhancement of the vasoprotective RAS components, particularly ACE2, will be critical for the future of cardiopulmonary disease therapy. Although the exact mechanism of ACE2 action is unknown, it is likely a consequence of both its catalytic and non-catalytic activity. Current therapies have focused 
on improving ACE2 enzymatic activity; however, given the ability of ACE2 to modulate gut microbiota, we anticipate that future therapies may also target the non-traditional aspects of ACE2 function.

\section{Acknowledgments}

Sources of Funding: This research was supported by NIH Grants: LJ 102033 and HL 056921 (awarded to MKR and MJK), SDG from the AHA: SDG-12080302 (awarded to VS), and Predoctoral from AHA: 14PRE18620024 (awarded to CTC).

\section{References}

1. Hall JE. Historical perspective of the renin-angiotensin system. Mol Biotechnol. 2003; 24(1):27-39. [PubMed: 12721494]

2. Paul M, Poyan Mehr A, Kreutz R. Physiology of local renin-angiotensin systems. Physiol Rev. 2006; 86(3):747-803. [PubMed: 16816138]

3. Fliser D, Buchholz K, Haller H. EUropean Trial on Olmesartan and Pravastatin in Inflammation and Atherosclerosis (EUTOPIA) Investigators Antiinflammatory effects of angiotensin II subtype 1 receptor blockade in hypertensive patients with microinflammation. Circulation. 2004; 110(9): 1103-1107. [PubMed: 15313950]

4. Ferrario CM, Strawn WB. Role of the renin-angiotensin-aldosterone system and proinflammatory mediators in cardiovascular disease. Am J Cardiol. 2006; 98(1):121-128. [PubMed: 16784934]

5. van Vark LC, Bertrand M, Akkerhuis KM, et al. Angiotensin-converting enzyme inhibitors reduce mortality in hypertension: A meta-analysis of randomized clinical trials of renin-angiotensinaldosterone system inhibitors involving 158,998 patients. Eur Heart J. 2012; 33(16):2088-2097. [PubMed: 22511654]

6. Yancy CW, Jessup M, et al. WRITING COMMITTEEMEMBERS. 2013 ACCF/AHA guideline for the management of heart failure: A report of the american college of cardiology foundation/ american heart association task force on practice guidelines. Circulation. 2013; 128(16):e240-e327. [PubMed: 23741058]

7. Gavras H, Brunner HR, Turini GA, et al. Antihypertensive effect of the oral angiotensin convertingenzyme inhibitor SQ 14225 in man. N Engl J Med. 1978; 298(18):991-995. [PubMed: 205788]

8. Konstam MA. Angiotensin converting enzyme inhibition in asymptomatic left ventricular systolic dysfunction and early heart failure. Eur Heart J. 1995; (16 Suppl N):59-64. [PubMed: 8682063]

9. Donoghue M, Hsieh F, Baronas E, et al. A novel angiotensin-converting enzyme-related carboxypeptidase (ACE2) converts angiotensin I to angiotensin 1-9. Circ Res. 2000; 87(5):E1-E9. [PubMed: 10969042]

10. Tipnis SR, Hooper NM, Hyde R, Karran E, Christie G, Turner AJ. A human homolog of angiotensin-convertings enzyme cloning and functional expression as a captopril-insensitive carboxypeptidase. J Biol Chem. 2000; 275(43):33238-33243. [PubMed: 10924499]

11. Tallant EA, Ferrario CM, Gallagher PE. Angiotensin-(1-7) inhibits growth of cardiac myocytes through activation of the mas receptor. Am J Physiol Heart Circ Physiol. 2005; 289(4):H1560 H1566. [PubMed: 15951342]

12. Grobe JL, Mecca AP, Mao H, Katovich MJ. Chronic angiotensin-(1-7) prevents cardiac fibrosis in DOCA-salt model of hypertension. Am J Physiol Heart Circ Physiol. 2006; 290(6):H2417-H2423. [PubMed: 16415071]

13. Qi Y, Shenoy V, Wong F, et al. Lentivirus-mediated overexpression of angiotensin-(1-7) attenuated ischaemia-induced cardiac pathophysiology. Exp Physiol. 2011; 96(9):863-874. [PubMed: 21685447]

14. Mehta PK, Griendling KK. Angiotensin II cell signaling: Physiological and pathological effects in the cardiovascular system. Am J Physiol Cell Physiol. 2007; 292(1):C82-C97. [PubMed: 16870827] 
15. Der Sarkissian S, Grobe JL, Yuan L, et al. Cardiac overexpression of angiotensin converting enzyme 2 protects the heart from ischemia-induced pathophysiology. Hypertension. 2008; 51(3): 712-718. [PubMed: 18250366]

16. Shenoy V, Ferreira AJ, Qi Y, et al. The angiotensin-converting enzyme 2/angiogenesis-(1-7)/mas axis confers cardiopulmonary protection against lung fibrosis and pulmonary hypertension. Am J Respir Crit Care Med. 2010; 182(8):1065-1072. [PubMed: 20581171]

17. Grobe JL, Mecca AP, Lingis M, et al. Prevention of angiotensin II-induced cardiac remodeling by angiotensin-(1-7). Am J Physiol Heart Circ Physiol. 2007; 292(2):H736-H742. [PubMed: 17098828]

18. Hernandez Prada JA, Ferreira AJ, Katovich MJ, et al. Structure-based identification of smallmolecule angiotensin-converting enzyme 2 activators as novel antihypertensive agents. Hypertension. 2008; 51(5):1312-1317. [PubMed: 18391097]

19. Loot AE, Roks AJ, Henning RH, et al. Angiotensin-(1-7) attenuates the development of heart failure after myocardial infarction in rats. Circulation. 2002; 105(13):1548-1550. [PubMed: 11927520]

20. Rodgers KE, Roda N, Felix JE, Espinoza T, Maldonado S, diZerega G. Histological evaluation of the effects of angiotensin peptides on wound repair in diabetic mice. Exp Dermatol. 2003; 12(6): 784-790. [PubMed: 14714558]

21. Oudit GY, Liu GC, Zhong J, et al. Human recombinant ACE2 reduces the progression of diabetic nephropathy. Diabetes. 2010; 59(2):529-538. [PubMed: 19934006]

22. Jarajapu YP, Bhatwadekar AD, Caballero S, et al. Activation of the ACE2/angiotensin-(1-7)/mas receptor axis enhances the reparative function of dysfunctional diabetic endothelial progenitors. Diabetes. 2013; 62(4):1258-1269. [PubMed: 23230080]

23. Chen J, Xiao X, Chen S, et al. Angiotensin-converting enzyme 2 priming enhances the function of endothelial progenitor cells and their therapeutic efficacy. Hypertension. 2013; 61(3):681-689. [PubMed: 23266545]

24. Yamazato M, Ferreira AJ, Yamazato Y, et al. Gene transfer of angiotensin-converting enzyme 2 in the nucleus tractus solitarius improves baroreceptor heart rate reflex in spontaneously hypertensive rats. J Renin Angiotensin Aldosterone Syst. 2011; 12(4):456-461. [PubMed: 21719524]

25. Xiao L, Gao L, Lazartigues E, Zucker IH. Brain-selective overexpression of angiotensinconverting enzyme 2 attenuates sympathetic nerve activity and enhances baroreflex function in chronic heart failure. Hypertension. 2011; 58(6):1057-1065. [PubMed: 22025374]

26. Yamazato M, Yamazato Y, Sun C, Diez-Freire C, Raizada MK. Overexpression of angiotensinconverting enzyme 2 in the rostral ventrolateral medulla causes long-term decrease in blood pressure in the spontaneously hypertensive rats. Hypertension. 2007; 49(4):926-931. [PubMed: 17325232]

27. Lu N, Yang Y, Wang Y, et al. ACE2 gene polymorphism and essential hypertension: An updated meta-analysis involving 11,051 subjects. Mol Biol Rep. 2012; 39(6):6581-6589. [PubMed: 22297693]

28. Patel SK, Wai B, Ord M, et al. Association of ACE2 genetic variants with blood pressure, left ventricular mass, and cardiac function in caucasians with type 2 diabetes. Am J Hypertens. 2012; 25(2):216-222. [PubMed: 21993363]

29. Lieb W, Graf J, Gotz A, et al. Association of angiotensin-converting enzyme 2 (ACE2) gene polymorphisms with parameters of left ventricular hypertrophy in men results of the MONICA augsburg echocardiographic substudy. J Mol Med (Berl). 2006; 84(1):88-96. [PubMed: 16283142]

30. van der Merwe L, Cloete R, Revera M, et al. Genetic variation in angiotensin-converting enzyme 2 gene is associated with extent of left ventricular hypertrophy in hypertrophic cardiomyopathy. Hum Genet. 2008; 124(1):57-61. [PubMed: 18560893]

31. Burrell LM, Harrap SB, Velkoska E, Patel SK. The ACE2 gene: Its potential as a functional candidate for cardiovascular disease. Clin Sci (Lond). 2013; 124(2):65-76. [PubMed: 23013041]

32. Mozaffarian D, Benjamin EJ, Go AS, et al. Heart disease and stroke statistics--2015 update: A report from the american heart association. Circulation. 2015; 131(4):e29-e322. [PubMed: 25520374] 
33. Yamamoto K, Ohishi M, Katsuya T, et al. Deletion of angiotensin-converting enzyme 2 accelerates pressure overload-induced cardiac dysfunction by increasing local angiotensin II. Hypertension. 2006; 47(4):718-726. [PubMed: 16505206]

34. Bodiga S, Zhong JC, Wang W, et al. Enhanced susceptibility to biomechanical stress in ACE2 null mice is prevented by loss of the p47(phox) NADPH oxidase subunit. Cardiovasc Res. 2011; 91(1): 151-161. [PubMed: 21285291]

35. Zhong J, Basu R, Guo D, et al. Angiotensin-converting enzyme 2 suppresses pathological hypertrophy, myocardial fibrosis, and cardiac dysfunction. Circulation. 2010; 122(7):717-728. 18 p following 728. [PubMed: 20679547]

36. Trask AJ, Groban L, Westwood BM, et al. Inhibition of angiotensin-converting enzyme 2 exacerbates cardiac hypertrophy and fibrosis in ren-2 hypertensive rats. Am J Hypertens. 2010; 23(6):687-693. [PubMed: 20300067]

37. Sahara M, Ikutomi M, Morita T, et al. Deletion of angiotensin-converting enzyme 2 promotes the development of atherosclerosis and arterial neointima formation. Cardiovasc Res. 2014; 101(2): 236-246. [PubMed: 24193738]

38. Huentelman MJ, Grobe JL, Vazquez J, et al. Protection from angiotensin II-induced cardiac hypertrophy and fibrosis by systemic lentiviral delivery of ACE2 in rats. Exp Physiol. 2005; 90(5): 783-790. [PubMed: 16049057]

39. Johnson JA, West J, Maynard KB, Hemnes AR. ACE2 improves right ventricular function in a pressure overload model. PLoS One. 2011; 6(6):e20828. [PubMed: 21695173]

40. Zhao YX, Yin HQ, Yu QT, et al. ACE2 overexpression ameliorates left ventricular remodeling and dysfunction in a rat model of myocardial infarction. Hum Gene Ther. 2010; 21(11):1545-1554. [PubMed: 20507236]

41. Dong B, Yu QT, Dai HY, et al. Angiotensin-converting enzyme-2 overexpression improves left ventricular remodeling and function in a rat model of diabetic cardiomyopathy. J Am Coll Cardiol. 2012; 59(8):739-747. [PubMed: 22340266]

42. Burrell LM, Risvanis J, Kubota E, et al. Myocardial infarction increases ACE2 expression in rat and humans. Eur Heart J. 2005; 26(4):369-375. discussion 322-4. [PubMed: 15671045]

43. Cohen-Segev R, Francis B, Abu-Saleh N, et al. Cardiac and renal distribution of ACE and ACE-2 in rats with heart failure. Acta Histochem. 2014

44. Zisman LS, Keller RS, Weaver B, et al. Increased angiotensin-(1-7)-forming activity in failing human heart ventricles: Evidence for upregulation of the angiotensin-converting enzyme homologue ACE2. Circulation. 2003; 108(14):1707-1712. [PubMed: 14504186]

45. Goulter AB, Goddard MJ, Allen JC, Clark KL. ACE2 gene expression is up-regulated in the human failing heart. BMC Med. 2004; 2:19. [PubMed: 15151696]

46. Kittleson MM, Minhas KM, Irizarry RA, et al. Gene expression analysis of ischemic and nonischemic cardiomyopathy: Shared and distinct genes in the development of heart failure. Physiol Genomics. 2005; 21(3):299-307. [PubMed: 15769906]

47. Batlle M, Roig E, Perez-Villa F, et al. Increased expression of the renin-angiotensin system and mast cell density but not of angiotensin-converting enzyme II in late stages of human heart failure. J Heart Lung Transplant. 2006; 25(9):1117-1125. [PubMed: 16962475]

48. Ohtsuki M, Morimoto S, Izawa $\mathrm{H}$, et al. Angiotensin converting enzyme 2 gene expression increased compensatory for left ventricular remodeling in patients with end-stage heart failure. Int J Cardiol. 2010; 145(2):333-334. [PubMed: 20060185]

49. Epelman S, Tang WH, Chen SY, Van Lente F, Francis GS, Sen S. Detection of soluble angiotensin-converting enzyme 2 in heart failure: Insights into the endogenous counter-regulatory pathway of the renin-angiotensin-aldosterone system. J Am Coll Cardiol. 2008; 52(9):750-754. [PubMed: 18718423]

50. Epelman S, Shrestha K, Troughton RW, et al. Soluble angiotensin-converting enzyme 2 in human heart failure: Relation with myocardial function and clinical outcomes. J Card Fail. 2009; 15(7): 565-571. [PubMed: 19700132]

51. Wang Y, Moreira Mda C, Heringer-Walther S, et al. Plasma ACE2 activity is an independent prognostic marker in chagas' disease and equally potent as BNP. J Card Fail. 2010; 16(2):157163. [PubMed: 20142028] 
52. Ortiz-Perez JT, Riera M, Bosch X, et al. Role of circulating angiotensin converting enzyme 2 in left ventricular remodeling following myocardial infarction: A prospective controlled study. PLoS One. 2013; 8(4):e61695. [PubMed: 23630610]

53. Uri K, Fagyas M, Manyine Siket I, et al. New perspectives in the renin-angiotensin-aldosterone system (RAAS) IV: Circulating ACE2 as a biomarker of systolic dysfunction in human hypertension and heart failure. PLoS One. 2014; 9(4):e87845. [PubMed: 24691269]

54. Shao Z, Shrestha K, Borowski AG, et al. Increasing serum soluble angiotensin-converting enzyme 2 activity after intensive medical therapy is associated with better prognosis in acute decompensated heart failure. J Card Fail. 2013; 19(9):605-610. [PubMed: 24054336]

55. Crackower MA, Sarao R, Oudit GY, et al. Angiotensin-converting enzyme 2 is an essential regulator of heart function. Nature. 2002; 417(6891):822-828. [PubMed: 12075344]

56. Feng Y, Xia H, Cai Y, et al. Brain-selective overexpression of human angiotensin-converting enzyme type 2 attenuates neurogenic hypertension. Circ Res. 2010; 106(2):373-382. [PubMed: 19926873]

57. Kar S, Gao L, Zucker IH. Exercise training normalizes ACE and ACE2 in the brain of rabbits with pacing-induced heart failure. J Appl Physiol (1985). 2010; 108(4):923-932. [PubMed: 20093667]

58. Xia H, Lazartigues E. Angiotensin-converting enzyme 2 in the brain: Properties and future directions. J Neurochem. 2008; 107(6):1482-1494. [PubMed: 19014390]

59. Feng Y, Yue X, Xia H, et al. Angiotensin-converting enzyme 2 overexpression in the subfornical organ prevents the angiotensin II-mediated pressor and drinking responses and is associated with angiotensin II type 1 receptor downregulation. Circ Res. 2008; 102(6):729-736. [PubMed: 18258853]

60. Sriramula S, Cardinale JP, Lazartigues E, Francis J. ACE2 overexpression in the paraventricular nucleus attenuates angiotensin II-induced hypertension. Cardiovasc Res. 2011; 92(3):401-408. [PubMed: 21952934]

61. Xia H, Suda S, Bindom S, et al. ACE2-mediated reduction of oxidative stress in the central nervous system is associated with improvement of autonomic function. PLoS One. 2011; 6(7):e22682. [PubMed: 21818366]

62. Jun JY, Zubcevic J, Qi Y, et al. Brain-mediated dysregulation of the bone marrow activity in angiotensin II-induced hypertension. Hypertension. 2012; 60(5):1316-1323. [PubMed: 23045460]

63. Zubcevic J, Jun JY, Kim S, et al. Altered inflammatory response is associated with an impaired autonomic input to the bone marrow in the spontaneously hypertensive rat. Hypertension. 2014; 63(3):542-550. [PubMed: 24366083]

64. Zhang M, Malik AB, Rehman J. Endothelial progenitor cells and vascular repair. Curr Opin Hematol. 2014; 21(3):224-228. [PubMed: 24637956]

65. Valgimigli M, Rigolin GM, Fucili A, et al. CD34+ and endothelial progenitor cells in patients with various degrees of congestive heart failure. Circulation. 2004; 110(10):1209-1212. [PubMed: 15249502]

66. Fritzenwanger M, Lorenz F, Jung C, et al. Differential number of CD34+, CD133+ and CD34+/ CD133+ cells in peripheral blood of patients with congestive heart failure. Eur J Med Res. 2009; 14(3):113-117. [PubMed: 19380281]

67. Heeschen C, Lehmann R, Honold J, et al. Profoundly reduced neovascularization capacity of bone marrow mononuclear cells derived from patients with chronic ischemic heart disease. Circulation. 2004; 109(13):1615-1622. [PubMed: 15037527]

68. Junhui Z, Xingxiang W, Guosheng F, Yunpeng S, Furong Z, Junzhu C. Reduced number and activity of circulating endothelial progenitor cells in patients with idiopathic pulmonary arterial hypertension. Respir Med. 2008; 102(7):1073-1079. [PubMed: 18394873]

69. Heringer-Walther S, Eckert K, Schumacher SM, et al. Angiotensin-(1-7) stimulates hematopoietic progenitor cells in vitro and in vivo. Haematologica. 2009; 94(6):857-860. [PubMed: 19377080]

70. Qi Y, Zhang J, Cole-Jeffrey CT, et al. Diminazene aceturate enhances angiotensin-converting enzyme 2 activity and attenuates ischemia-induced cardiac pathophysiology. Hypertension. 2013; 62(4):746-752. [PubMed: 23959549] 
71. Shenoy V, Gjymishka A, Jarajapu YP, et al. Diminazene attenuates pulmonary hypertension and improves angiogenic progenitor cell functions in experimental models. Am J Respir Crit Care Med. 2013; 187(6):648-657. [PubMed: 23370913]

72. He H, Liu L, Chen Q, et al. Mesenchymal stem cells overexpressing angiotensin-converting enzyme 2 rescue lipopolysaccharide-induced lung injury. Cell Transplant. 2014

73. Liu F, Gao F, Li Q, Liu Z. The functional study of human umbilical cord mesenchymal stem cells harbouring angiotensin-converting enzyme 2 in rat acute lung ischemia-reperfusion injury model. Cell Biochem Funct. 2014; 32(7):580-589. [PubMed: 25230251]

74. Li W, Moore MJ, Vasilieva N, et al. Angiotensin-converting enzyme 2 is a functional receptor for the SARS coronavirus. Nature. 2003; 426(6965):450-454. [PubMed: 14647384]

75. Imai Y, Kuba K, Penninger JM. The discovery of angiotensin-converting enzyme 2 and its role in acute lung injury in mice. Exp Physiol. 2008; 93(5):543-548. [PubMed: 18448662]

76. Yang P, Gu H, Zhao Z, et al. Angiotensin-converting enzyme 2 (ACE2) mediates influenza H7N9 virus-induced acute lung injury. Sci Rep. 2014; 4:7027. [PubMed: 25391767]

77. Zou Z, Yan Y, Shu Y, et al. Angiotensin-converting enzyme 2 protects from lethal avian influenza A H5N1 infections. Nat Commun. 2014; 5:3594. [PubMed: 24800825]

78. Liu X, Yang N, Tang J, et al. Downregulation of angiotensin-converting enzyme 2 by the neuraminidase protein of influenza A (H1N1) virus. Virus Res. 2014; 185:64-71. [PubMed: 24662240]

79. Li G, Liu Y, Zhu Y, et al. ACE2 activation confers endothelial protection and attenuates neointimal lesions in prevention of severe pulmonary arterial hypertension in rats. Lung. 2013; 191(4):327-336. [PubMed: 23652350]

80. Yuan YM, Luo L, Guo Z, Yang M, Ye RS, Luo C. Activation of renin-angiotensin-aldosterone system (RAAS) in the lung of smoking-induced pulmonary arterial hypertension (PAH) rats. J Renin Angiotensin Aldosterone Syst. 2015; 16(2):249-253. [PubMed: 25795458]

81. Shenoy V, Kwon KC, Rathinasabapathy A, et al. Oral delivery of angiotensin-converting enzyme 2 and angiotensin-(1-7) bioencapsulated in plant cells attenuates pulmonary hypertension. Hypertension. 2014

82. de Man FS, Tu L, Handoko ML, et al. Dysregulated renin-angiotensin-aldosterone system contributes to pulmonary arterial hypertension. Am J Respir Crit Care Med. 2012; 186(8):780 789. [PubMed: 22859525]

83. Dai HL, Guo Y, Guang XF, Xiao ZC, Zhang M, Yin XL. The changes of serum angiotensinconverting enzyme 2 in patients with pulmonary arterial hypertension due to congenital heart disease. Cardiology. 2013; 124(4):208-212. [PubMed: 23548773]

84. Dai H, Gong Y, Xiao Z, Guang X, Yin X. Decreased levels of serum angiotensin-(1-7) in patients with pulmonary arterial hypertension due to congenital heart disease. Int J Cardiol. 2014; 176(3): 1399-1401. [PubMed: 25150487]

85. Takahashi Y, Haga S, Ishizaka Y, Mimori A. Autoantibodies to angiotensin-converting enzyme 2 in patients with connective tissue diseases. Arthritis Res Ther. 2010; 12(3):R85. [PubMed: 20470389]

86. Yamazato Y, Ferreira AJ, Hong KH, et al. Prevention of pulmonary hypertension by angiotensinconverting enzyme 2 gene transfer. Hypertension. 2009; 54(2):365-371. [PubMed: 19564552]

87. Kleinsasser A, Pircher I, Treml B, et al. Recombinant angiotensin-converting enzyme 2 suppresses pulmonary vasoconstriction in acute hypoxia. Wilderness Environ Med. 2012; 23(1):24-30. [PubMed: 22441085]

88. Li X, Molina-Molina M, Abdul-Hafez A, Uhal V, Xaubet A, Uhal BD. Angiotensin converting enzyme-2 is protective but downregulated in human and experimental lung fibrosis. Am J Physiol Lung Cell Mol Physiol. 2008; 295(1):L178-L185. [PubMed: 18441099]

89. Rey-Parra GJ, Vadivel A, Coltan L, et al. Angiotensin converting enzyme 2 abrogates bleomycininduced lung injury. J Mol Med (Berl). 2012; 90(6):637-647. [PubMed: 22246130]

90. Hashimoto T, Perlot T, Rehman A, et al. ACE2 links amino acid malnutrition to microbial ecology and intestinal inflammation. Nature. 2012; 487(7408):477-481. [PubMed: 22837003] 
91. Harmer D, Gilbert M, Borman R, Clark KL. Quantitative mRNA expression profiling of ACE 2, a novel homologue of angiotensin converting enzyme. FEBS Lett. 2002; 532(1-2):107-110. [PubMed: 12459472]

92. Zhang H, Wada J, Hida K, et al. Collectrin, a collecting duct-specific transmembrane glycoprotein, is a novel homolog of ACE2 and is developmentally regulated in embryonic kidneys. J Biol Chem. 2001; 276(20):17132-17139. [PubMed: 11278314]

93. Danilczyk U, Sarao R, Remy C, et al. Essential role for collectrin in renal amino acid transport. Nature. 2006; 444(7122):1088-1091. [PubMed: 17167413]

94. Camargo SM, Singer D, Makrides V, et al. Tissue-specific amino acid transporter partners ACE2 and collectrin differentially interact with hartnup mutations. Gastroenterology. 2009; 136(3):872882. [PubMed: 19185582]

95. Kowalczuk S, Broer A, Tietze N, Vanslambrouck JM, Rasko JE, Broer S. A protein complex in the brush-border membrane explains a hartnup disorder allele. FASEB J. 2008; 22(8):2880-2887. [PubMed: 18424768]

96. Murr C, Grammer TB, Kleber ME, Meinitzer A, Marz W, Fuchs D. Low serum tryptophan predicts higher mortality in cardiovascular disease. Eur J Clin Invest. 2015; 45(3):247-254. [PubMed: 25586781]

97. Karapetyan AV, Klyachkin YM, Selim S, et al. Bioactive lipids and cationic antimicrobial peptides as new potential regulators for trafficking of bone marrow-derived stem cells in patients with acute myocardial infarction. Stem Cells Dev. 2013; 22(11):1645-1656. [PubMed: 23282236]

98. Korthuis RJ, Gute DC, Blecha F, Ross CR. PR-39, a proline/arginine-rich antimicrobial peptide, prevents postischemic microvascular dysfunction. Am J Physiol. 1999; 277(3 Pt 2):H1007-H1013. [PubMed: 10484423]

99. Ikeda Y, Young LH, Scalia R, Ross CR, Lefer AM. PR-39, a proline/arginine-rich antimicrobial peptide, exerts cardioprotective effects in myocardial ischemia-reperfusion. Cardiovasc Res. 2001; 49(1):69-77. [PubMed: 11121797]

100. Higazi AA, Lavi E, Bdeir K, et al. Defensin stimulates the binding of lipoprotein (a) to human vascular endothelial and smooth muscle cells. Blood. 1997; 89(12):4290-4298. [PubMed: 9192751]

101. Higazi AA, Nassar T, Ganz T, et al. The alpha-defensins stimulate proteoglycan-dependent catabolism of low-density lipoprotein by vascular cells: A new class of inflammatory apolipoprotein and a possible contributor to atherogenesis. Blood. 2000; 96(4):1393-1398. [PubMed: 10942383]

102. Kougias P, Chai H, Lin PH, Yao Q, Lumsden AB, Chen C. Defensins and cathelicidins: Neutrophil peptides with roles in inflammation, hyperlipidemia and atherosclerosis. J Cell Mol Med. 2005; 9(1):3-10. [PubMed: 15784160]

103. Zhao H, Yan H, Yamashita S, et al. Acute ST-segment elevation myocardial infarction is associated with decreased human antimicrobial peptide LL-37 and increased human neutrophil peptide-1 to 3 in plasma. J Atheroscler Thromb. 2012; 19(4):357-368. [PubMed: 22186100]

104. Edfeldt K, Agerberth B, Rottenberg ME, et al. Involvement of the antimicrobial peptide LL-37 in human atherosclerosis. Arterioscler Thromb Vasc Biol. 2006; 26(7):1551-1557. [PubMed: 16645154]

105. Serino M, Luche E, Chabo C, Amar J, Burcelin R. Intestinal microflora and metabolic diseases. Diabetes Metab. 2009; 35(4):262-272. [PubMed: 19419895]

106. Galassi A, Reynolds K, He J. Metabolic syndrome and risk of cardiovascular disease: A metaanalysis. Am J Med. 2006; 119(10):812-819. [PubMed: 17000207]

107. Yang T, Santisteban MM, Rodriguez V, et al. Gut dysbiosis is linked to hypertension. Hypertension. 2015; 65(6):1331-1340. [PubMed: 25870193]

108. Agerholm-Larsen L, Raben A, Haulrik N, Hansen AS, Manders M, Astrup A. Effect of 8 week intake of probiotic milk products on risk factors for cardiovascular diseases. Eur J Clin Nutr. 2000; 54(4):288-297. [PubMed: 10745279]

109. Kawase M, Hashimoto H, Hosoda M, Morita H, Hosono A. Effect of administration of fermented milk containing whey protein concentrate to rats and healthy men on serum lipids and blood pressure. J Dairy Sci. 2000; 83(2):255-263. [PubMed: 10714858] 
110. Naruszewicz M, Johansson ML, Zapolska-Downar D, Bukowska H. Effect of lactobacillus plantarum 299v on cardiovascular disease risk factors in smokers. Am J Clin Nutr. 2002; 76(6): 1249-1255. [PubMed: 12450890]

111. Seppo L, Jauhiainen T, Poussa T, Korpela R. A fermented milk high in bioactive peptides has a blood pressure-lowering effect in hypertensive subjects. Am J Clin Nutr. 2003; 77(2):326-330. [PubMed: 12540390]

112. Aihara K, Kajimoto O, Hirata H, Takahashi R, Nakamura Y. Effect of powdered fermented milk with lactobacillus helveticus on subjects with high-normal blood pressure or mild hypertension. $\mathrm{J}$ Am Coll Nutr. 2005; 24(4):257-265. [PubMed: 16093403]

113. Dong JY, Szeto IM, Makinen K, et al. Effect of probiotic fermented milk on blood pressure: A meta-analysis of randomised controlled trials. Br J Nutr. 2013; 110(7):1188-1194. [PubMed: 23823502]

114. Chen Y, Liu W, Xue J, et al. Angiotensin-converting enzyme inhibitory activity of lactobacillus helveticus strains from traditional fermented dairy foods and antihypertensive effect of fermented milk of strain H9. J Dairy Sci. 2014

115. Khalesi S, Sun J, Buys N, Jayasinghe R. Effect of probiotics on blood pressure: A systematic review and meta-analysis of randomized, controlled trials. Hypertension. 2014; 64(4):897-903. [PubMed: 25047574]

116. Lin MY, Yen CL. Reactive oxygen species and lipid peroxidation product-scavenging ability of yogurt organisms. J Dairy Sci. 1999; 82(8):1629-1634. [PubMed: 10480088]

117. Lin MY, Chang FJ. Antioxidative effect of intestinal bacteria bifidobacterium longum ATCC 15708 and lactobacillus acidophilus ATCC 4356. Dig Dis Sci. 2000; 45(8):1617-1622. [PubMed: 11007114]

118. Kullisaar T, Zilmer M, Mikelsaar M, et al. Two antioxidative lactobacilli strains as promising probiotics. Int J Food Microbiol. 2002; 72(3):215-224. [PubMed: 11845820]

119. Kullisaar T, Songisepp E, Mikelsaar M, Zilmer K, Vihalemm T, Zilmer M. Antioxidative probiotic fermented goats' milk decreases oxidative stress-mediated atherogenicity in human subjects. Br J Nutr. 2003; 90(2):449-456. [PubMed: 12908907]

120. Songisepp E, Kals J, Kullisaar T, et al. Evaluation of the functional efficacy of an antioxidative probiotic in healthy volunteers. Nutr J. 2005; 4:22. [PubMed: 16080791]

121. Wang YC, Yu RC, Chou CC. Antioxidative activities of soymilk fermented with lactic acid bacteria and bifidobacteria. Food Microbiol. 2006; 23(2):128-135. [PubMed: 16942996]

122. Jarvenpaa S, Tahvonen RL, Ouwehand AC, Sandell M, Jarvenpaa E, Salminen S. A probiotic, lactobacillus fermentum ME-3, has antioxidative capacity in soft cheese spreads with different fats. J Dairy Sci. 2007; 90(7):3171-3177. [PubMed: 17582099]

123. Mikelsaar M, Zilmer M. Lactobacillus fermentum ME-3 - an antimicrobial and antioxidative probiotic. Microb Ecol Health Dis. 2009; 21(1):1-27. [PubMed: 19381356]

124. Agerholm-Larsen L, Bell ML, Grunwald GK, Astrup A. The effect of a probiotic milk product on plasma cholesterol: A meta-analysis of short-term intervention studies. Eur J Clin Nutr. 2000; 54(11):856-860. [PubMed: 11114681]

125. Xiao JZ, Kondo S, Takahashi N, et al. Effects of milk products fermented by bifidobacterium longum on blood lipids in rats and healthy adult male volunteers. J Dairy Sci. 2003; 86(7):24522461. [PubMed: 12906063]

126. Wang Y, Xu N, Xi A, Ahmed Z, Zhang B, Bai X. Effects of lactobacillus plantarum MA2 isolated from tibet kefir on lipid metabolism and intestinal microflora of rats fed on highcholesterol diet. Appl Microbiol Biotechnol. 2009; 84(2):341-347. [PubMed: 19444443]

127. Ramchandran L, Shah NP. Proteolytic profiles and angiotensin-I converting enzyme and alphaglucosidase inhibitory activities of selected lactic acid bacteria. J Food Sci. 2008; 73(2):M75M81. [PubMed: 18298740]

128. Ellis CL, Bokulich NA, Kalanetra KM, et al. Probiotic administration in congenital heart disease: A pilot study. J Perinatol. 2013; 33(9):691-697. [PubMed: 23599119]

129. Koren O, Spor A, Felin J, et al. Human oral, gut, and plaque microbiota in patients with atherosclerosis. Proc Natl Acad Sci U S A. 2011; (108 Suppl 1):4592-4598. [PubMed: 20937873] 
130. Gan XT, Ettinger G, Huang CX, et al. Probiotic administration attenuates myocardial hypertrophy and heart failure after myocardial infarction in the rat. Circ Heart Fail. 2014; 7(3):491-499. [PubMed: 24625365]

131. Tanida M, Yamano T, Maeda K, Okumura N, Fukushima Y, Nagai K. Effects of intraduodenal injection of lactobacillus johnsonii La1 on renal sympathetic nerve activity and blood pressure in urethane-anesthetized rats. Neurosci Lett. 2005; 389(2):109-114. [PubMed: 16118039]

132. McVey Neufeld KA, Mao YK, Bienenstock J, Foster JA, Kunze WA. The microbiome is essential for normal gut intrinsic primary afferent neuron excitability in the mouse. Neurogastroenterol Motil. 2013; 25(2):183-e188. [PubMed: 23181420]

133. Kiliaan AJ, Saunders PR, Bijlsma PB, et al. Stress stimulates transepithelial macromolecular uptake in rat jejunum. Am J Physiol. 1998; 275(5 Pt 1):G1037-G1044. [PubMed: 9815034]

134. Ait-Belgnaoui A, Durand H, Cartier C, et al. Prevention of gut leakiness by a probiotic treatment leads to attenuated HPA response to an acute psychological stress in rats. Psychoneuroendocrinology. 2012; 37(11):1885-1895. [PubMed: 22541937]

135. Dickson RP, Martinez FJ, Huffnagle GB. The role of the microbiome in exacerbations of chronic lung diseases. Lancet. 2014; 384(9944):691-702. [PubMed: 25152271]

136. Han MK, Zhou Y, Murray S, et al. Lung microbiome and disease progression in idiopathic pulmonary fibrosis: An analysis of the COMET study. Lancet Respir Med. 2014; 2(7):548-556. [PubMed: 24767767]

137. Wang H, Liu JS, Peng SH, et al. Gut-lung crosstalk in pulmonary involvement with inflammatory bowel diseases. World J Gastroenterol. 2013; 19(40):6794-6804. [PubMed: 24187454]

138. Madan JC, Koestler DC, Stanton BA, et al. Serial analysis of the gut and respiratory microbiome in cystic fibrosis in infancy: Interaction between intestinal and respiratory tracts and impact of nutritional exposures. MBio. 2012; 3(4)

139. Popova M, Molimard P, Courau S, et al. Beneficial effects of probiotics in upper respiratory tract infections and their mechanical actions to antagonize pathogens. J Appl Microbiol. 2012; 113(6): 1305-1318. [PubMed: 22788970]

140. Ferreira AJ, Santos RA, Bradford CN, et al. Therapeutic implications of the vasoprotective axis of the renin-angiotensin system in cardiovascular diseases. Hypertension. 2010; 55(2):207-213. [PubMed: 20038757]

141. Haschke M, Schuster M, Poglitsch M, et al. Pharmacokinetics and pharmacodynamics of recombinant human angiotensin-converting enzyme 2 in healthy human subjects. Clin Pharmacokinet. 2013; 52(9):783-792. [PubMed: 23681967]

142. Kulemina LV, Ostrov DA. Prediction of off-target effects on angiotensin-converting enzyme 2. J Biomol Screen. 2011; 16(8):878-885. [PubMed: 21859683]

143. Ferreira AJ, Shenoy V, Yamazato Y, et al. Evidence for angiotensin-converting enzyme 2 as a therapeutic target for the prevention of pulmonary hypertension. Am J Respir Crit Care Med. 2009; 179(11):1048-1054. [PubMed: 19246717]

144. Li G, Xu YL, Ling F, et al. Angiotensin-converting enzyme 2 activation protects against pulmonary arterial hypertension through improving early endothelial function and mediating cytokines levels. Chin Med J (Engl). 2012; 125(8):1381-1388. [PubMed: 22613639]

145. Peregrine AS, Mamman M. Pharmacology of diminazene: A review. Acta Trop. 1993; 54(3-4): 185-203. [PubMed: 7902657]

146. Haber PK, Ye M, Wysocki J, Maier C, Haque SK, Batlle D. Angiotensin-converting enzyme 2independent action of presumed angiotensin-converting enzyme 2 activators: Studies in vivo, ex vivo, and in vitro. Hypertension. 2014; 63(4):774-782. [PubMed: 24446061]

147. Velkoska E, Patel SK, Griggs K, Pickering RJ, Tikellis C, Burrell LM. Short-term treatment with diminazene aceturate ameliorates the reduction in kidney ACE2 activity in rats with subtotal nephrectomy. PLoS One. 2015; 10(3):e0118758. [PubMed: 25786223]

148. Fraga-Silva RA, Costa-Fraga FP, Murca TM, et al. Angiotensin-converting enzyme 2 activation improves endothelial function. Hypertension. 2013; 61(6):1233-1238. [PubMed: 23608648]

149. Fraga-Silva RA, Sorg BS, Wankhede M, et al. ACE2 activation promotes antithrombotic activity. Mol Med. 2010; 16(5-6):210-215. [PubMed: 20111697] 
150. Ferreira AJ, Shenoy V, Qi Y, et al. Angiotensin-converting enzyme 2 activation protects against hypertension-induced cardiac fibrosis involving extracellular signal-regulated kinases. Exp Physiol. 2011; 96(3):287-294. [PubMed: 21148624]

151. Qiu Y, Shil PK, Zhu P, et al. Angiotensin-converting enzyme 2 (ACE2) activator diminazene aceturate ameliorates endotoxin-induced uveitis in mice. Invest Ophthalmol Vis Sci. 2014; 55(6): 3809-3818. [PubMed: 24854854]

152. Thatcher SE, Zhang X, Howatt DA, et al. Angiotensin-converting enzyme 2 decreases formation and severity of angiotensin II-induced abdominal aortic aneurysms. Arterioscler Thromb Vasc Biol. 2014; 34(12):2617-2623. [PubMed: 25301841]

153. Zhang Y, Liu J, Luo JY, et al. Upregulation of angiotensin (1-7)-mediated signaling preserves endothelial function through reducing oxidative stress in diabetes. Antioxid Redox Signal. 2015

154. Mecca AP, Regenhardt RW, O'Connor TE, et al. Cerebroprotection by angiotensin-(1-7) in endothelin-1-induced ischaemic stroke. Exp Physiol. 2011; 96(10):1084-1096. [PubMed: 21685445]

155. Haga S, Tsuchiya H, Hirai T, Hamano T, Mimori A, Ishizaka Y. A novel ACE2 activator reduces monocrotaline-induced pulmonary hypertension by suppressing the JAK/STAT and TGF-beta cascades with restored caveolin-1 expression. Exp Lung Res. 2015; 41(1):21-31. [PubMed: 25275723]

156. Kirkpatrick JN, St John Sutton M. Assessment of ventricular remodeling in heart failure clinical trials. Curr Heart Fail Rep. 2012; 9(4):328-336. [PubMed: 22983907]

157. Bleumink GS, Knetsch AM, Sturkenboom MC, et al. Quantifying the heart failure epidemic: Prevalence, incidence rate, lifetime risk and prognosis of heart failure the rotterdam study. Eur Heart J. 2004; 25(18):1614-1619. [PubMed: 15351160]

158. Min F, Gao F, Li Q, Liu Z. Therapeutic effect of human umbilical cord mesenchymal stem cells modified by angiotensin-converting enzyme 2 gene on bleomycin-induced lung fibrosis injury. Mol Med Rep. 2015; 11(4):2387-2396. [PubMed: 25435005]

159. Ruf S, Karcher D, Bock R. Determining the transgene containment level provided by chloroplast transformation. Proc Natl Acad Sci U S A. 2007; 104(17):6998-7002. [PubMed: 17420459]

160. Scotti N, Cardi T. Plastid transformation as an expression tool for plant-derived biopharmaceuticals. Methods Mol Biol. 2012; 847:451-466. [PubMed: 22351028] 


\section{Angiotensinogen}

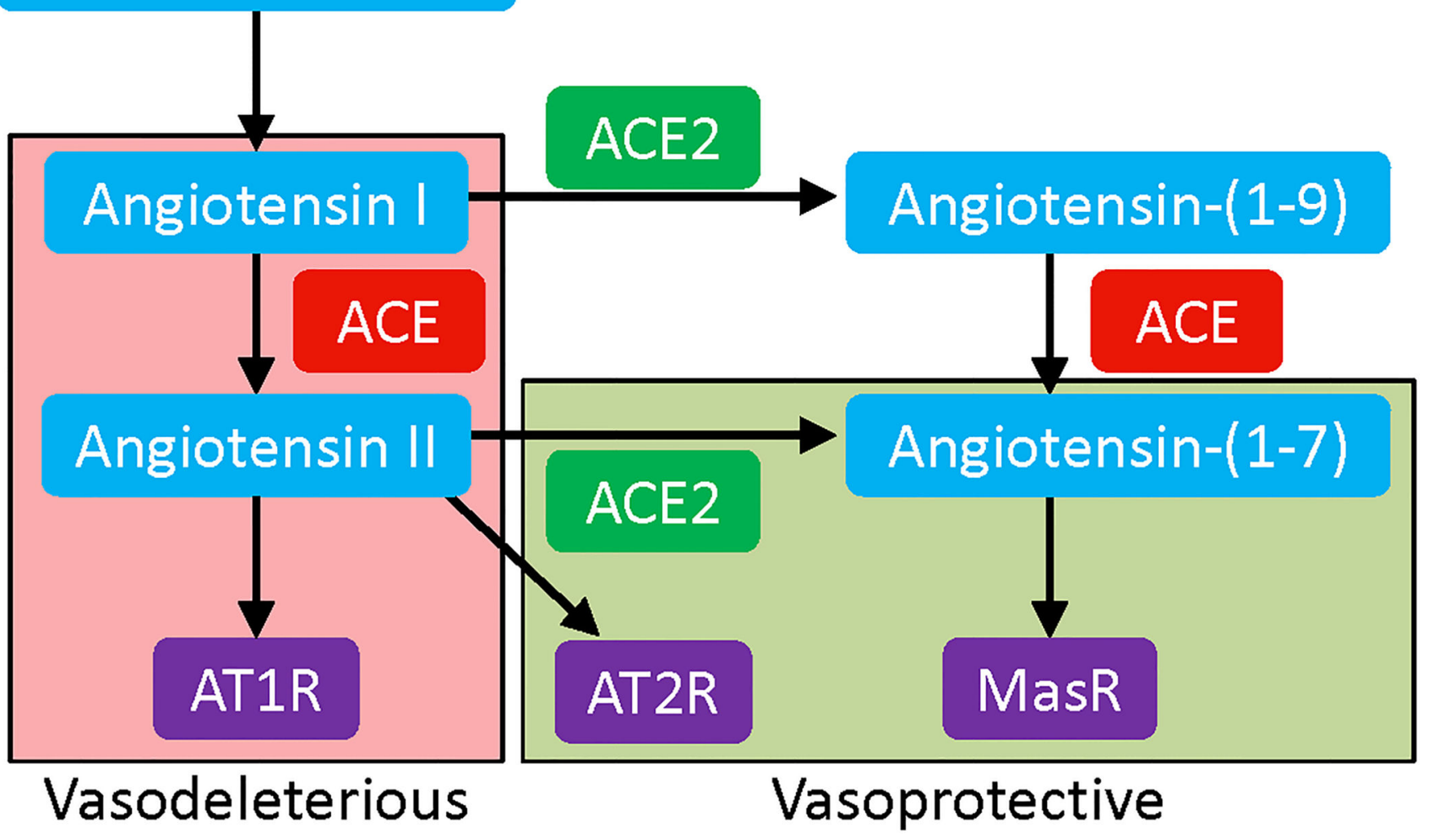

Figure 1.

Components of the vasodeleterious and vasoprotective axes of the RAS. 


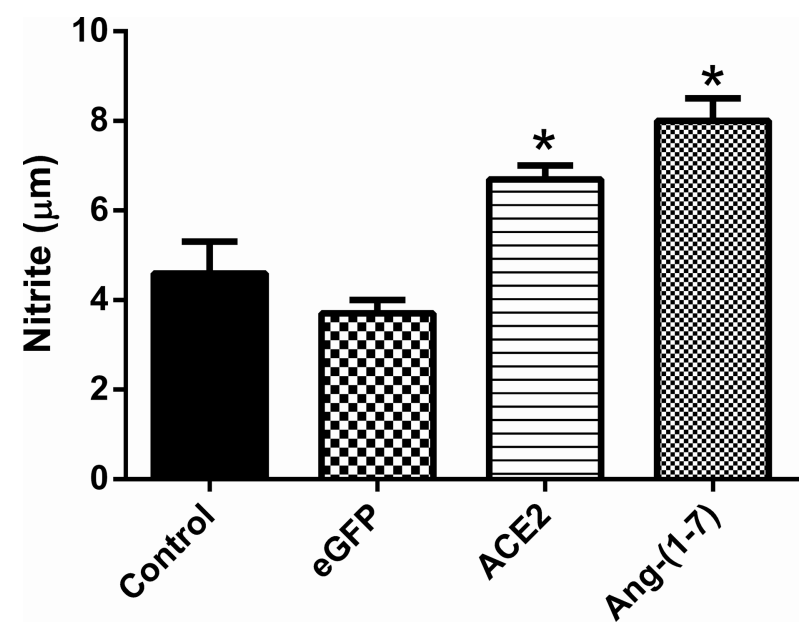

Figure 2.

Cultured rat MSCs were infected with 50 multiplicity of infection (MOI) of lenti-eGFP, lenti-ACE2, or lenti-Ang-(1-7). Control was uninfected MSCs. Lenti-eGFP served as viral transduction control. Data are expressed as mean \pm SEM. ${ }^{*} \mathrm{p}<0.05$ vs Control \& eGFP groups. 


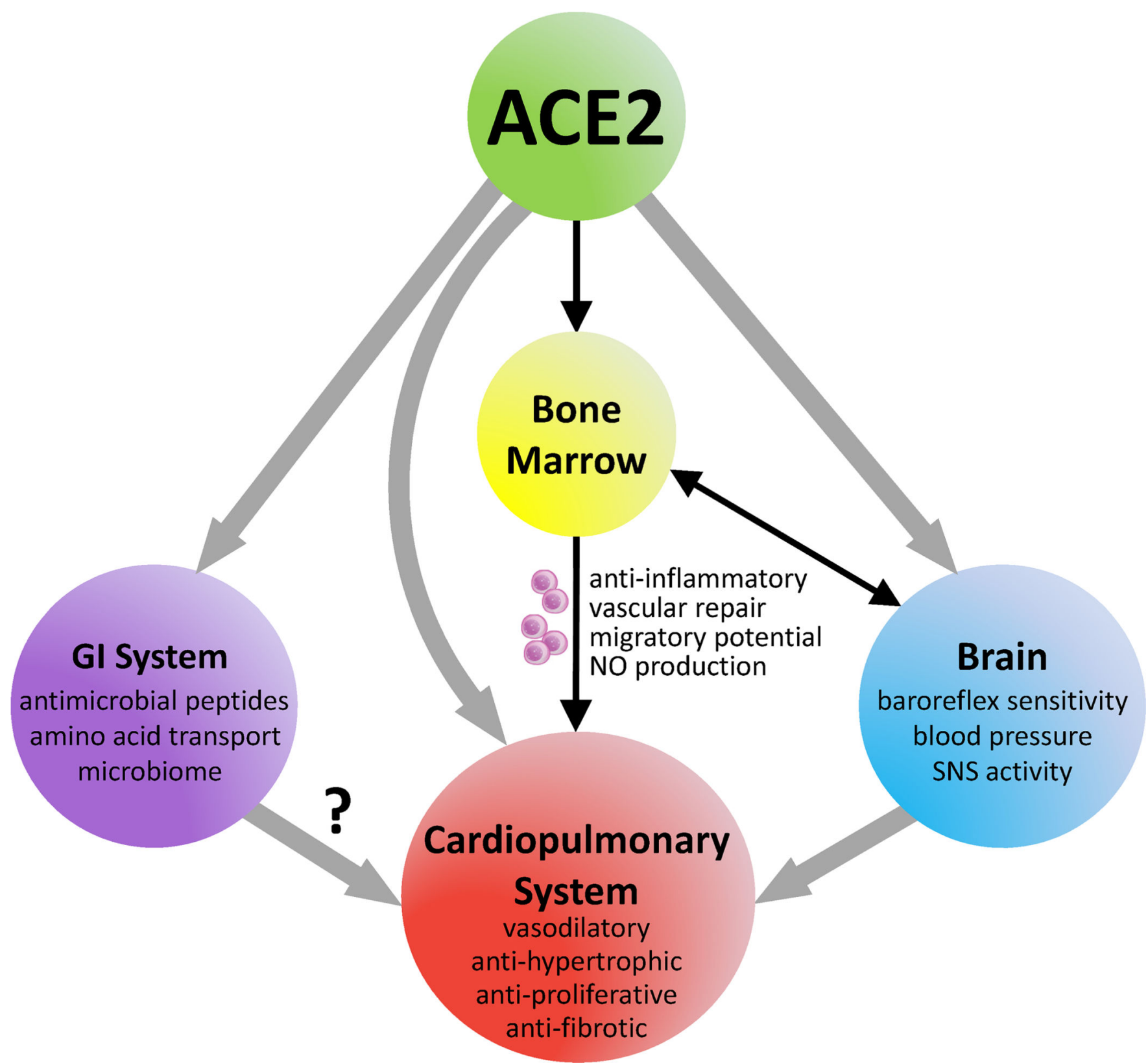

Figure 3.

Influences of ACE2 on body systems and the subsequent implications on cardiopulmonary health. SNS = sympathetic nervous system. 